Portland State University

PDXScholar

5-1971

\title{
Continuance vs. Discontinuance in Family Counseling
}

Katherine Anderson

Portland State University

Alice Dudley

Portland State University

Mayetta Rocks

Portland State University

Follow this and additional works at: https://pdxscholar.library.pdx.edu/open_access_etds

Part of the Counseling Psychology Commons, Social Psychology and Interaction Commons, and the Social Work Commons

Let us know how access to this document benefits you.

\section{Recommended Citation}

Anderson, Katherine; Dudley, Alice; and Rocks, Mayetta, "Continuance vs. Discontinuance in Family Counseling" (1971). Dissertations and Theses. Paper 1455.

https://doi.org/10.15760/etd.1454

This Thesis is brought to you for free and open access. It has been accepted for inclusion in Dissertations and Theses by an authorized administrator of PDXScholar. Please contact us if we can make this document more accessible: pdxscholar@pdx.edu. 
CONPINUANCE vs. DISCONTINUAKCE

IN FAMILY COURSELING

\author{
by \\ Satherine Anderson \\ Alice Dudley \\ Mayetta Bocks
}

\author{
Consultant Committee: \\ Dr. A. Fmien \\ Mrs. C. MoKinney \\ Dx. G. Pinamont1
}

\title{
Portland State University \\ School of Sooial Work
}

Kay, 1971 


\section{CONTINUANCE VS. DISCONTINOANCE IN FAMILY COUNSELING}

\section{Objectives}

The study was designed to examine the socialworkers' and clients' perceptions of change in the treatment process; specifically, to examine the question of why clients discontinue service prior to planful termination. Also, the authors attempted to assess the client's perception of gain and the worker's assessment of gain.

\section{Significant Findings}

1. Seventy-two per cent of the clients who responded to the questionnaire felt they had been helped. In those cases where the client indicated he had received no help or that his situstion became worse, the authors found that the client often indicated that his spouse was unable or unwilling to participate in treatment. These clients also often indicated thot they had divorced.

2. The client tended to rate the gains be mode from treatment olightly higher than the worker rated them.

3. The inability or unwillingness of the spouse to participate in the treatment process was seen as an important reason for discontinuance before six interviews were completed.

4. The client seemed more likely to indicate fee as a reason for termination of service after six interviews.

5. Clients who paid no fee were more likely to terminate in an unplanned manner before six interviews. If the client paid any fee, his termination was more likely to be planful. 
Recommendations and Suggestions for Further Research

1. The authors recommend that workers indicate clearly on the siatistical cards which member of the family were seen in order to facilitate and expedite data gathering.

2. The statistical cards igive assessment of service in terms of gain only. The authors recommend that because service is not always gainful, that there be a place on the statistical card to so indicate this. The situation may be so deteriorated that in the worker's assessment there is no ability on the part of the client for motivation, capacity and opportunity for change.

3. On the basis of the data derived from the questionnaire, the authors recommend that further exploratory study be done in the following areas:

a. In the cases where the spouse is unable or unwilling to participate in the treatment process.

b. In the cases where the clients who paid no fee were more likely to terminate unplanned and before six interviews.

4. The authors recommend, as in the study done by Dr. Dan Jennings, that any questionnaire mailed out by the agency in the future be a more immediate follow-up to treatment, that is, there is a need for further exploration of the optimum time for follow-up study. A future questionnaire might be returned to the individual practitioner so that he could evaluate the service. Also a planned follow-up of this sort might result in the practitioner reaching out to the client to re-involve him in the treatment process if the c:ient so indicated the need on the returned questionnaire. 
5. Findings in this study showed that the critical period for clients continuance seems to be within the first five interviews. The authors recommend that further exploratory study be done on this critical period of treatment. 


\section{INTRODUCTION}

In a period of management by objectives, financial retrenchments, concern for greater efficiency in use of staff and evaluation of efficacy of social work services, agency boards, executives and staff are asking many questions such as: are our agency services meeting the needs of our clients; do the families we attempt to help actually change; to what extent; in what ways? Further, is there congruence between the workers' assessment of change and the clients' perception of the help they receive?

Corresponding inquiries are coming from other segments of the community, planning councils, findings bodies and governmental sources responsible for allocating and distributing the commity resources. Therefore, accountability becomes an important factor. The main question becomes, are the needs of the community being met in the best possible anner? Again, this relates direotly to the desire of the aocial work profession to upgrade practice in accordance with the changing times. Consequently, there is a pressing need for evaluation of service from the standpoint of those who serve and those who receive 8ervice.

Research in social work has frequently been focused upon an examination of the efficacy of social work help. For example, in "Continuance in Casework and Other Helping Relationships: A Review of Current Research," (Levinger, 1960) the authors found that continuance seems to be function of numerous variables having to do with the clients' attributes and environment and the workers' attributes and environment. A corollary interest has been in the question of why the clients 
discontinue service. For example, factors in discontinuancy of service in "Some Theoretical and Practical Problems in Eraluating Effectiveness of Counseling," (Ba1lard and Madd, 1957) the authors found that there were discrepancies between the client's view and the worker's view of change in the counseling process.

In Portland, The Family Counseling Service Agency has had a continuing interest in the effectiveness of treatment. In 1970, the agency employed Dr. Jennings of the Portland State Oniversity School of Social Work to conduct a limited study in this subject. As students ploced in Family Counseling Service for field rork, the authors were interested in fulfilling their research requirement in their field agenoy. The executive director and field instructors were queried regarding possible research topics and once again the subjeot of discontinuance was introduced. 


\section{METHODOLOGY}

In the Family Coungeling Service Agency of Portland the problem most of ten presented by the client is categorized as marital (as opposed to total family or parent-child problems). Consequently, the authors deoided to limit the study of continuance rs. discontinuance to this category. Oniformly, a worker evaluated a case at termination. The otatistical card is the tool by which this task is accomplished. The nature of the study called for the use of completed records and as this study was undertaken in 1970, the authors used the completed statistical cards on marital cases from the year 1969 representing the total tricounty area (Washington, Clackamas, and Wultnomab counties). The total population consisted of 283 completed cases.

The statistical cards (see appendix) are an important source for collection of data. The atatistical card gives factual data about family members (age, sex, income, etc.), factual information bout service, and also documents an evaluation of service as seen by the vorker. The evaluation of service actually consists of (1) the worker's judgment as to whether or not service was terminated by casework plan or whether the family withdrew or terminated service in an unplanned manner, and (2) the worker's assessment of client gain.

In this study, therefore, continuance is defined as a planned completion of service, that is, termination of service is made by mutual decision between worker and client regardless of the number of interriews. Conversely, discontinuance is defined as unplanned termination of service, that is, the client, by his own decision, withdrew from 
sorvice (often for reasons unknown to the vorker).

The worker in assessing client change is allowed to indicate on the statistical card the following choices:

1. eubstantial gain

2. moderate gain

3. slight gain

4. no change

5. unable to determine

Thus the worker has two judgmental decisions to make: 1) regarding planfulness, and 2) regarding client gain. The authors attempt in this study to relate these two judgmental decisions to factual information about the number of in-person interviews the worker has had with the client. The attempt was to explore the interrelationshipe between the three faotors: planfulness, gain, and number of interviews.

In analyzing the cards, the authors accepted the vorker's statements that the olient's identified problem was maxital as well as the number of in-person interviews indicated on the card by the worker in the categories such as: one interview, two to five interviews, six or more interviews. The authors eliminated any contacts that were by telephone or correspondence only and/or collateral contacte; because the study was focused on the relationship between planfulness, gain, and the number of in-person interviews between client and worker.

After presenting the findings derived from the lnitial investigation of the statistical cards to the Family Counseling Agency, the authors thought that a further study should be made which would compare the data showing the worker's assessment of client change in relation to the three selected variables, number of interviews, planfulness and gain, and the 
client's assessment of change. More specifically, the authors wanted to know whether or not the client saw termination as a joint decision between hinself and the vorker or did he withdraw on his own, and if 80 , for what reason? Also, they wished to know whether or not the client perceived change in terms of gain, and whether or not there was a relationship between the number of interviews and the client's perception of planfulness and gain? Finally, did the client's assessment agree or disagree with the worker's asseasment?

In devising an effective instrument for gathering the necessaxy data sevexal factors became important - namely, time, cost, and procedure involved in contacting cliente. The study had to be originated and completed within eix veek time period and costs had to be kept to a bere minimum. Consequently, this ruled out any in-person interviews.

In the prior study done for the agency in 1970, "Planned Short Term Treatment Project Follow-up Study" by Dr. Dan Jeanings (1970), it was shown that the population under consideration was bighly mobile and transient. The authors decided to use the entire population of 283 marital cases for the collection of data so that they could gather a fuller return in each category than could be anticipated by random sampling procedures. Therefore, a simple mail-out questionnaire seemed the most appropriate instrument to use. It was immediately realized because of the time and the minimal financial resources that any consideration of a follow-up procedure of those questionnaires not returned within the time limit was an impossibility.

In designing the questionnaire, tho firet step was to examine the pertinent literature and extant questionnaires pertaining to prior en- 
deavors concermed with client-agency change in evaluation of counseling. This included the Family Forum Questionnaire of Family Counseling Service as vell as the current FSA pilot "Census Study of Families Served." The authors devised a seven question form which allowed for collection of data pertinent to the variables of planfulness, gain and number of interviews. This form was presented to the resesch consultants of Portland State University and the final form was then submitted to the Director of the Family Counseling Service for approval. The questionnaire (Bee appendix) was mailed on Febreary 5, 1971. The final date for acceptance of completed questionnaires into the study was February 26, 1971. A total of 72 completed questionnaires vere returned, a twentyfive per cent return.

It may be noted that this is a poor response rate, howerer, in Dr. Jennings' study done after only aix months, the response rate was slightly less than fifty per cent. Thus both studies seem to emphasize the highly mobile and transient character of olients served by this agency.

\section{FINDLWGS}

In examining the total population derived from the statistical card the authors found that there were a total of 93 one-interview cases. There were 79 cases in the two-to-five interview category, and 111 in the six-or-more interview category.

In the one interview cases, the workers assessed 69 , a majority, of these as unplanned termination and 24 as planned. In the tro-to-five category, the workers indicated 47 unplanned terminations and 32 planned ones. In the category of six-or-more interviews, only 30 were unplanned 
terminations and 81 vere planned.

\section{TABLE I}

MOMBER OF INTERVIEWS RESLATED TO PLANWULNESS OF TERMTNATION

\begin{tabular}{|c|c|c|c|}
\hline $\begin{array}{l}\text { A. } \\
\text { Number of Interviews }\end{array}$ & One & Two to Pive & Six or More \\
\hline Termination unplanned & 69 & 47 & 30 \\
\hline Termination planned & 24 & 32 & 81 \\
\hline $\begin{array}{l}\text { B. } \\
\text { Number of Interviews }\end{array}$ & Six to Ten & Eleven to Twent & Twenty-one \\
\hline Termination unplanned & 23 & 6 & 1 \\
\hline Termination planned & 43 & 23 & 15 \\
\hline
\end{tabular}

$\Delta s$ the data in Table I indicates, when the case is terminated after one interview, the worker tends to show it as unplanned. According to the vorker's interpretations, following this the greater the number of interviews the wore tendency to show the termination a being planned. Irving Fowler, in "Family Agency Characteristics and Client Continuance" reported rates of non-return to second interviews tend to cluster around thirty-three per cent. About thirty-tbree per cent are lost after two to three interviews and thirty-three per cent continue into four or more interviews. 
Table II indicates the worker's assessment of gain as related to the number of interviews. This information is further broken down in Table III. The type of termination as determined by the worker seems to be related to whether or not he saw gain. Therefore, it appears that planned termination is closely related to measurable gain on the part of the client. Stated another way, the greater the number of interviews the more the worker tended to see them as planned termination. The data shows that in all cases seen by the workers as showing no change, the number of interviews is always in the one-to-five interview category and termination is oeen as unplanned. In the aix-or-more interview category the vorker always saw some gain. Therefore, the material leavea us with at least two conclusions: 1) the worker tends to perceive termination as unplanned where they did not seo gain, 2) the worker does not seom to indicate gain when a client stopped coming for unknown reasons. 
TABLE II

EVALUATIOA OF SBRICE

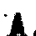

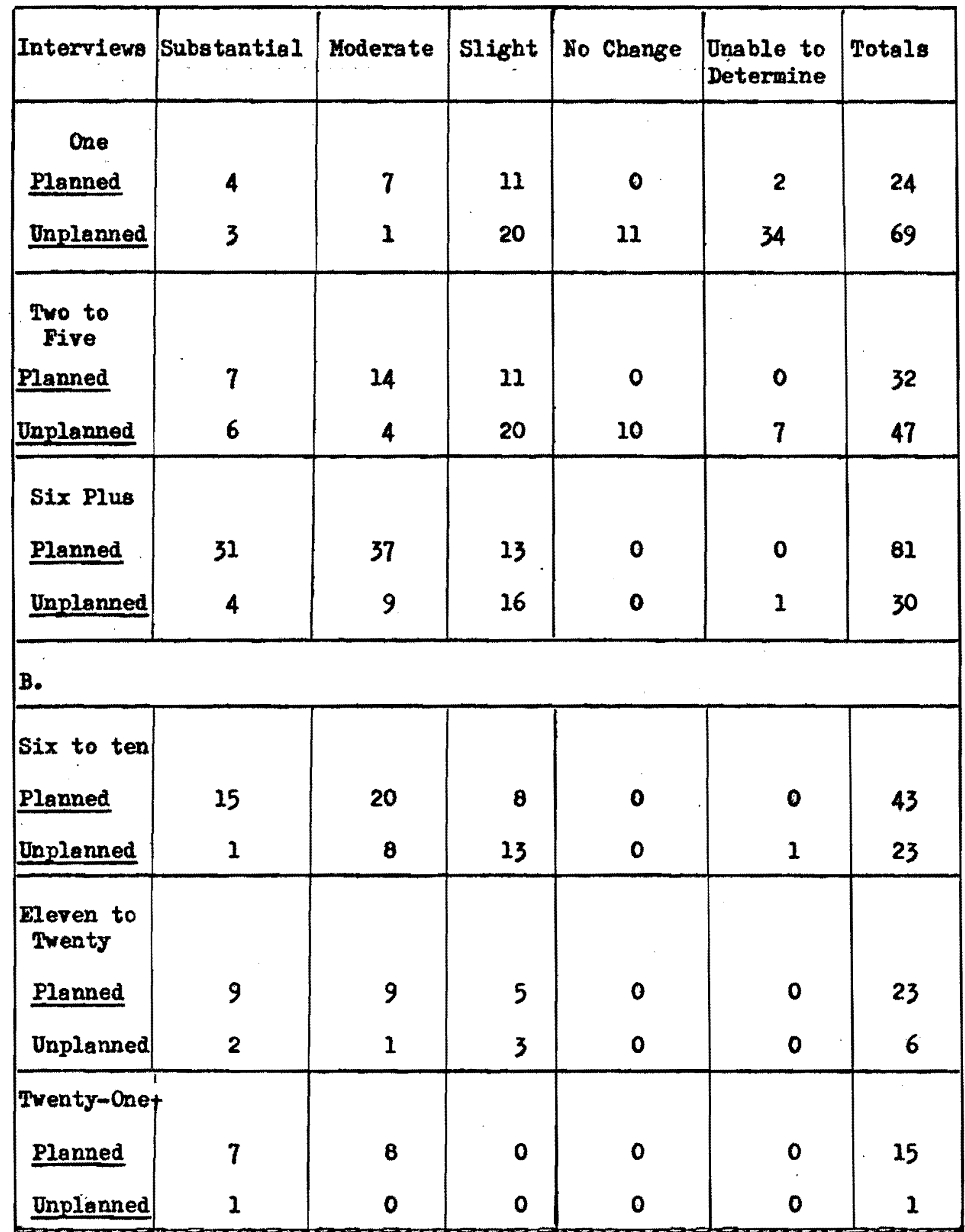


TABIT III

GAIN RELATED TO PLNNTULNBSS OF TERMINATION

\begin{tabular}{|l|c|c|}
\hline \multicolumn{2}{|l|}{ A. } & \\
\hline Degree of Gain & Planned & Onplanned \\
\hline Substantial & 42 & 13 \\
\hline Yoderate & 58 & 14 \\
\hline Slight & 34 & 56 \\
\hline No Change & 0 & 21 \\
\hline Toral & 234 & 104 \\
\hline B. & 134 & 27 \\
\hline Termination & Planned & Onplanned \\
\hline Moderate to Substantial & 100 & 71 \\
\hline
\end{tabular}


TABIE IV

FES RELATED TO NUMBER OF INTERVIEWS AND CONTINUANCE

\begin{tabular}{|c|c|c|c|c|c|c|}
\hline Interviews & 0 & $1-5$ & $6-10$ & $11-15$ & $16-20$ & $21-25$ \\
\hline \multicolumn{7}{|l|}{ One } \\
\hline Planned - & 7 & 6 & 4 & 6 & 0 & 1 \\
\hline Unplanned & 20 & 17 & 9 & 17 & 3 & 3 \\
\hline \multicolumn{7}{|l|}{ Two to Five } \\
\hline Planned & 1 & 13 & 5 & 10 & 1 & 2 \\
\hline Unplanned & 16 & 11 & 8 & 10 & 1 & 1 \\
\hline \multicolumn{7}{|l|}{ Six or More } \\
\hline Planned & 16 & 22 & 14 & 25 & 2 & 2 \\
\hline Unplanned & 10 & 7 & 6 & 5 & 1 & 1 \\
\hline \multicolumn{7}{|c|}{ B. Total Number of Terminations Disregarding Number of Interviews } \\
\hline Dollare per week & 0 & $1-5$ & $6-10$ & $11-15$ & $-16-20$ & $21-25$ \\
\hline Planned & 24 & 41 & 23 & 41 & 3 & 5 \\
\hline Unplanned & 46 & 35 & 23 & 32 & 5 & 5 \\
\hline Total & 70 & 76 & 46 & 73 & 8 & 10 \\
\hline
\end{tabular}

Table IV indicates that the majority of clients pay fees in the zero to five dollar category. Those clients who pay no fee are less likely to planfully terminate service especially before six interviews. If the client pays any fee, he is more likely to terminate by plan. 
INTERPRETATIONS OF QUESTIONNAIRE

A total of 283 questionnaires were mailed out. Forty-nine were returned by the post office because they were unable to locate the client. Of this number there were only 18 cases where new addresses could not be found. Seventy-two completed questionnaires (see appendix) were returned to the agency - twenty-five per cent (25\%) of the total. Returns were as follows:

Number of Questionnaires

One interview:

Two to five interviews:

Six or more interviews:
Nailed 93

79

111
Returned 18 33

The following is an examination of the client's assessment of eervice receitred:

I. Assessment of the Problem

The first and second questions required the client to describe the problem which brought him to the agency. Of the seventy-two (72) returns, sixty-eight (68) clients saw their problem as a husband-wife problem, three (3) indicated a personal problem only, one (1) did not indicate a problem.

Although there was a basic agreement between worker and client perception of the problem as being of a "marital nature," that is, conflict between the spouses, the clients clarified the outstanding symptoms of the marital conflict in their written statements as follows: 


$\begin{array}{lr}\text { lack of communication } & 12 \\ \text { alcoholism } & 6 \\ \text { personal problen } & 7 \\ \text { parent-child difficulties } & 5 \\ \text { finsncial problems } & 5 \\ \text { sexual problems } & 4 \\ \text { physical problems } & 2 \\ \text { problems with in-laws } & 2 \\ \text { housekeoping difficulties } & 1\end{array}$

II. Assessment of help received and gains made

In questions 3 and 4 , the client was asked for his perception of the help he received at the agency. Of the seventytwo responses to the questionnaire, fifty-two (52) clients felt they had received some help (72\%), nine (9) felt they had not been helped at all (12\%), and eleven (11) felt that things got worse (15\%). (See Table V.) : In comparing the client's perceptions and the vorker's perceptions of the gains ade, the authors found that the client has a tendency to rate his gains slightly higher than his vorker. There also tends to be more agreement between the vorker and the client where there is substantial or moderate gains. 
PABIE $\mathbf{\gamma}$

ASSESSMENT OF HELP RECETVED AND GAINS HADE

4. Worker Assessment Compared to Client Assessment of Gain

\section{GAINS}

WORKER

ASSESSMENT

CLIENT ASSBSSMERT

\begin{tabular}{|l|c|c|c|c|c|c|}
\hline & $\begin{array}{c}\text { Great } \\
\text { deal }\end{array}$ & Some & L little & $\begin{array}{c}\text { Not at } \\
\text { all }\end{array}$ & $\begin{array}{c}\text { Things got } \\
\text { worse }\end{array}$ & Totals \\
\hline Substantial & 9 & 8 & 2 & 1 & 0 & 20 \\
\hline Moderate & 6 & 5 & 4 & 2 & 4 & 21 \\
\hline Slight & 6 & 6 & 3 & 2 & 4 & 21 \\
\hline Mo change & 0 & 0 & 1 & 1 & 0 & 2 \\
\hline Unable to \\
determine
\end{tabular}

B. Combined Categories of gain

\begin{tabular}{|c|c|c|}
\hline Worker Rating & \multicolumn{3}{|c|}{ Client Rating } \\
& + & - \\
\hline+ & 49 & 13 \\
\hline- & 3 & 7 \\
\hline
\end{tabular}


In important finding was that as the number of interviows increases both the cllent and worker tend to perceive more gains as ohow in Table vI.

\section{TABLE VI}

HOMBER OF INTERVIEWS COMPARED TO WORKER AND CLIENT VIEW OF GAIN

\begin{tabular}{|l|c|c|c|}
\hline Interviews & & Gain & Ho Gain \\
\hline \multirow{2}{*}{ One } & Worker & 14 & 7 \\
\cline { 2 - 4 } & Client & 11 & 10 \\
\hline Two to five & Worker & 15 & 3 \\
\cline { 2 - 5 } Six or more & Client & 14 & 4 \\
\hline \multirow{2}{*}{ Total } & Worker & 33 & 0 \\
\cline { 2 - 5 } & Client & 27 & 6 \\
\hline
\end{tabular}

Gain - substantial, moderate, slight

Ho gain = no change, unable to determine

In those eleven cases where the client indicated that "things got vorse," the authors found f:om other date on the questionnaire that seven of these clients indicated that they got a divorce, seven of these clients also indicated that their opouses vere unable or unwilling to participate in counseling. In six ingtances the client had only one interview, the other five clients were interviewed more than six times. As in the findings of the Jennings' study, where he found that thirty-one 
per cent (31\%) of the responses indicated that gervice would have been more helpful had more members of the family been able to participate, the authors feel that possibly more effective ways need to be explored to involve all significant family members in the treatment process.

In those nine cases where the client indicated he had not been helped at all, five indicated that they were dissatisfied with their worker, two gave no information, two said spouse unable to participate. In four instances the client was interviewed once, four clients were seen two to five times, and one client was seen more than six times.

\section{Terminations}

In questions 5 and 6 whioh deal with the clients perception of termination of service, the authors found that the client tends to agree with the worker's perception of whether terwination was planned or unplanned, especially after six interviews as shown in Table VII. 
TABLE VII

CLIENT AND WORKER PERCEPTIONS OF TERMTHATION

OF SERVICE

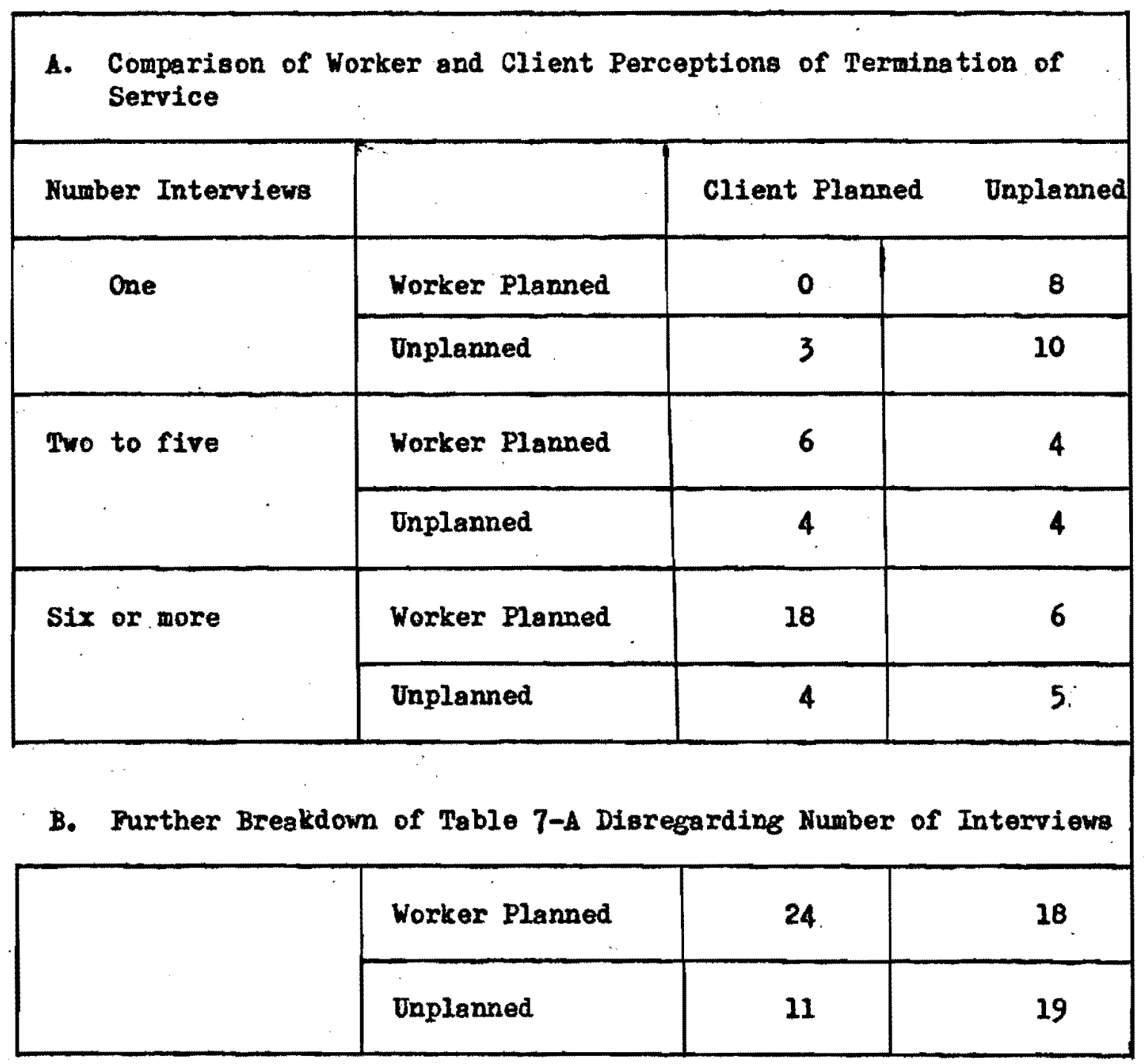

IV. OTHER IMPORTANT REASONS FOR TERMINATION WITH THE AGENCY

In question 7 , the client was asked if other reasons made it necessary for him to terminate. The client's responses sometimes showed more than one reason per client for termination. 
TABLE VIII

OTHER IMPORTANT REASONS FOR TERMLATION

\begin{tabular}{|l|c|c|c|}
\hline \multicolumn{1}{|c|}{ R3ASON } & $\begin{array}{c}\text { One Inter- } \\
\text { view }\end{array}$ & $\begin{array}{c}\text { Two to Pive } \\
\text { Interviews }\end{array}$ & $\begin{array}{c}\text { Six or More } \\
\text { Interviews }\end{array}$ \\
\hline Fee & 3 & 2 & 10 \\
\hline $\begin{array}{l}\text { Spouse ungble to } \\
\text { participate }\end{array}$ & 6 & 8 & 7 \\
\hline $\begin{array}{l}\text { Transportation or } \\
\text { distance }\end{array}$ & 1 & 1 & 2 \\
\hline Agency hours & 0 & 0 & 3 \\
\hline Moved & 3 & 0 & 1 \\
\hline Child care & 1 & 4 & 7 \\
\hline Found help elsewhere & 0 & 0 & 1 \\
\hline Other & 3 & 0 & 1 \\
\hline
\end{tabular}

In Table VIII, the fact that the spouse is unable to participate appeare to have no relationship to the number of interviews. Inability of the spouse to participate accounts for about one half of the client reasons for discontinuance before oix interviews, according to our data. After six interviews, this reason accounts for less than one-fifth.

When the client indicated that the amount of the fee influenced his termination with the agency, it appears that he was more likely to see the fee as a resson for termingtion after six interviews. 
In investigating these fifteen cases which saw the fee as a resson for termination, six of the clients had been paying less than $\$ 6.00$ per week, three had been paying from $\$ 6.00$ to $\$ 10.00$ per week, four olients had been paying from $\$ 11.00$ to $\$ 15.00$ per week, and two had been paying from $\$ 21.00$ to $\$ 25.00$ per week. As pointed out in Table IX, the amoun.t of the foe does not seem especially relevant.

TABLE IX

FEE AS A FACTOR IN TERMIMATION COMPARED TO NOMBER OF INTERVIEWS

\begin{tabular}{|l|c|c|c|c|c|c|}
\hline Number Interviews & $\$ 0-5$ & $\$ 6-10$ & $\$ 11-15$ & $\$ 16-20$ & $\$ 21-25$ & Total \\
\hline One & 2 & 1 & 0 & 0 & 0 & 3 \\
\hline Two to five & 1 & 0 & 0 & 0 & 1 & 2 \\
\hline Six or more & 3 & 2 & 4 & 0 & 1 & 10 \\
\hline Total & 6 & 3 & 4 & 0 & 2 & 25 \\
\hline
\end{tabular}

of this same group of clients, eight regarded termination as their decision alone, seven saw the decision as a joint deciaion between themselves and their worker.

\section{v. SUMMARY IMPLICATIONS AND CONCLUSIONS}

This study has touched on the dual perspective of socialworkers and clients in an attempt to identify their perceptions of change in the treatment process. It was done in an effort to explore some of the factors that relate to the question why clients discontinue service 
before planful termination.

To accomplish this objective, all marital cases with in-person interviews closed in the year 1969, a total of 283 cases, were reviewed in terms of three factors: the number of interviews, planfulness of termination, and gains mede during the process. Fron this, data was obtained that indicated the caseworker's viewpoint. Secondly, to assess the client's view of these same variables a questionnaire vas employed. From a twenty-five per cent return, seventy-two responses, comparable data was derived which allowed for a comparative study.

Because of the limited size of the return of the questionnaire, deductions are tentative and guarded. Nonetheless, the authors feel the following considerations are in order

1. Both worker and client tend to see the identified problem as the eame, that is, marital, as opposed to parent-child, total family or environmental.

2. Clients as a whole tend to see slightly more gain in the treatwent process than the worker. An exception was in the area were the client indicated on the questionnaire that things got worse, $i$. e., in his view there was deterioration rather than gain. These differences in perception might be related to the following factors:

a. The socialworker assesses gain in relation to the actual treatment process while in fact gain in functioning depends for support and confirmation on influences entirely outside of the social casework process.

b. The client's response to the questionnaire may be 
influenced by the intervening time between termination and the filling out of the questionnaire.

c. In those cases where the client indicated that he had not been helped at all, i. e., the situational sspects of the problem may not have changed (e.g., the alcoholic apouse), the worker may have indicated gain because the client evidenced progress in coping with the particular problem or situation.

3. The data indicates that when the spouse is unable to participate early in the counseling process, continuance is less likely. Approximately thirty per cent (30\%) of the total returned questionnairea indicated that "spouse being unable to perticipate" was a factor relating to termination. of the thirty per cent, two thirds texminated before aix interviews.

a. The authors speculate that if the workers can be encouraged to identify and help the client cope with this fact early in the treatment process and focus on the immediate pressure of the apouse being unable to participate, the agency might lose fewer clients prematurely.

b. The authors also speculate that where the apouse is unable or unwilling to participate in individual counseling, an effort might be made to involve this spouse, perhaps by using more marital group counseling.

4. Clients who gave fee costs as a reason for termination were asually those who had been interviewed more than five times. It oeems that as the fee accumulates over a period of time and 
becomes a more significant amount, the client, consequently, begins to see the fee as a drain on his resources.

5. Yet, from the investigation of the statistical cards, it was found that clients who pay no fee are more likely to terminate unplanned and before six interviews. This might be related to the following factors.

a. Clients who pay a fee may place more value on counseling since it "costs something," and therefore may have more of a commitment.

b. Clients who pay no fee may have problems of a financial nature which may be one symptom of more basic dysfunction in their lives. If they are somewhat irresponsible financially, this irresponsibility probably appears in other areas of functioning. (Some writers see problems as coming in clusters.)

c. Clients who pay no fee may be those who have more difficulty in meeting the necessary costs of keeping appointments at the agency such as transportation, child care, etc.

In looking critically at the instrument used in this study to gather data on client assessment, the authors believe that the following additional observations are justified:

1. The clients seemed to be well able to make the judgments calied for, which reinforces the idea that the clients are the best source of information concerning gains made in the treatment process as pointed out in Sacks, Bradley and Beck, Clients 
Progress within Five Interviews; An Exploratory Study Comparing Worker and Clients Views.

2. As pointed out in Dr. Jennings' study, "Planned Short Term Treatment Project Follow-up Study," the population under consideration was of a highly mobile and transient nature. His study pointed out that it was difficult to contact the clients all of whom had been seen at the agency very recently. The current study utilized cases closed as long as two years prior to mailing the follow-up questionnaire. The authors realized that this compounded the difficulty in obtaining data.

3. The data received from the questionnaire was that which the the authors intended to obtain. The only exception was in Question \#6 which related to the decision to terminate. The client had been asked whether or not it was his decision alone to stop coming. Sezeral clients indicated that they perceived this question to mean that it was only one spouse's decision rather than the partners' decision. Further misunderstanding was indicated from their responses when asked if it were a joint decision between "you and your worker," the client several times responded that one spouse and the counselor made a joint decision, but the other partner was not in agreement. Therefore, the authors realize that any comparison between client and worker assessment of termination is difficult because of the different meaning of the question to the client as opposed to the author's intent. Consequently; the authors believe that the findings derived from Table VII tend to be invalid. 
In looking critically at the instrument which was the source of data for the vorker's assessment (the statistical cards), the authors reoggized that it was difficult to assees deterioration or negative ohanges within the treatment process 88 the statiatical card is limited to rating of positive change categories.

On the basis of this study, it was concluded that much further exploration and evaluation of service in relation to termination needs to be done. Specifically, further study needs to be conducted in the area where the spouse is unable to participate in treatment. 


\section{BIBLIOGRAPHY}

Adams, Wesley T., "Clients, Counselors and Pees," The Pamily Coordinator, Vol. 17, \#4, October, 1964 .

Ballard, Robert G. and Mudd, Bmily H., "Some Souroes of Differences between Client and Agency Evaluation of Effectiveness of Counseling," Social Casework, Vol. XXXIX, No. 1, January, 1958.

Ballard, Robert G. and Madd, Enily H., "Some Theoretical and Practical Problen in Evaluating fffectiveness of Counseling," Social Casework, Vol. XXXXIIII, No. 10, December, 1957.

Beck, Dorothy Fahs, Patterng in Dee of the Family Agency, Family Service Assoclation of America, New York, 1962.

Bitterman, Catherine M., "Serving Applicants When there is a Waiting List," Social Casework, Vol. 34, Ho. 6, June, 1958.

Bleukner, M., Hunt, J. M., Xogan, L. S., "A Study of Interrelated Factors in the Initial Interviews with Clients," Social Casework, Vol. XXXII, January, 1951.

Briar, Scott, "The Casework Predicament," Social Work, Vol. XIII, No. 1, January, 1968.

Brigg, Elvira H., The Application Problem: A Study of Why People Fail To Keep First Appointments," Social Work, Vol. 10, No. 2, April, 1965.

Brown, Selma, "Time Cortent and horkex as Factors in Discontinuity," Smith College Studies in Soclal Work, June 1966, Vol, XXXXVI, \#3.

Chilman, Catherine S. (Ed.), Approsches to the Measurement of Pamily Clarize, Welfare Research Report 4, U. S. Department of Health, Education and Welfare, Washington, D. C., 1966. 
Fanshed, David, "A Study of Caseworkers' Perceptions of Their Clients," Social Casevork, Vol. XXXIX, December,1958.

Freeman, J. J., et.al., "Factors Associated with Success of Failure in Iarital Counseling," Damily Coordinator, Vol. B, April, 1969.

Fowler, Irving A., "Family Agency Characteristics and Client Continuances," Social Casework, Vol. XIVIII, No. 5, May 1967.

Garcia, Ralph A., and Irwin, Olive, "A Family Afency Deals with Probleme of Dropouts," Social Casework, Vol. 43, No. 2, February 1962.

Geibman, I. I. and Ayers, Beverly, "A Nethod for Bvaluating the Social Functioning of Families Under Treatment," Social Work, Vol. IX, No. 1, January, 1959.

Graham, Henry L. and Blumenthal, David L., Why We Failed - As clients See It," Family Service Highlights, Vol. XVI, June, 1955.

Gundlach, Ralph, "The Problem of Early Terminationt Is It Really The Terminee?" Journal Consulting Psycholosx, Vol. XXII, December, 1958.

Bunt, J. M. and Kogan, I., "Measuring Results in Social Casework," Pamily Service Aseociation of America, New York, 1950.

Hunt, J. M., "On the Judgment of Social Workers 88 a Source of Information in Social Work Research," in Dge of Judgments as Dats in Social Work, Ann W. Shyne, editor, National Association of Social Workers, 1959.

Jennings, D. E. " "Planned Short Team Treatment Project Follnw Up Study," (unpublished manuscripth May, 1970.

Kogan, Leonard S., "The Short Term Case in Family Agency," Social Cagerork, Vol. XXXVIII, No. 5, 6, and 7 (May, June, and July, 1957). 
Kogan, Leonard S., Hunt, J. M. and Bartelme, Phyllis, A Follow-up Study of the Results of Social Casevork, Family Service Association of America, New York, 1953.

Krause, Mexton S., "Pxedicting Client Discontinuance at Intake," Social Casevork, Vol. 43, No. 6, June 1962.

Levinger, George, "Continuance in Casework and Other Helping Relationohips: A Review of Current Research," Social Work, Vol. 5, No. 3 , July 1960, pp. 40-51.

Yayer, John E. and Rosenblatt, Aaron, "The Clients Social Context: Its Effect on Continuance in Treatment," Social Casework, Vol. XIV, Hovember, 1964.

Wayer, John E. and Timms, Noel, "Clash in Perspective Between Workers and Client," Social Casework, Vol. I., Ho. 1, January, 1969:

Mayer, Henry J., Borgatta, Edgar F. and Jones, Wyatt C,; Girls at Vocational High: AN Experiment in Social Work Intervention, Russell Sage Foundation, Hew York, 1965.

Most, Elizabeth, "Mearruing Change in Marital Satisfaction," Social Work, Vol. IX, No. 3, July, 1964.

Parad, Howard J. (Bd.), Crisis Intervention: Selected Readings, Family Service Association of America, New York, 1965.

Perlman, Helen Harris, "Can Casework Work?" Social Service Review, Vol. XIII, No, 4, December 1968.

Perlman, Helen H. "Some Notes on the Waiting List," Social Casework, Vol. 44, No. 4, April, 1963.

Polangky, Norman and Koumin, Jacob, "Clients Reaction to Initial Interviews, a Field Study," Human Relations, Vol. IX, August, 1956. 
Reid, William J. and Shyne, Ann W.2 Brief and Extended Casework, Columbia Univereity Press, New York, 1969.

Reid, William J., "Client and Practioner Variablee Affecting Treatment," Social Cosework, Vol. XIV, No. 10, December, 1964.

Ripple, Lillian, "Factors Associated with Casework Service," Social Work, Vol. 2, No. 1, January, 1957.

Bipple, Lillian, Alexander, Ernestina, and Polemis, Bernice W., Motiration, Capacity and Opportunity, Social Service Monographs, Second Series, University of Chicago, Chicago, 1964.

Rosenblatt, Aaron and Mayer, John, "Client Disengagement and Alternative Treatment Resources," Social Casework. Vol. XIVIII, No. 1, January, 1966.

Sacks, Joel G., Bradley, Panke M., Beck, Dorothy F., nClients Progress Within Five Interviews: AN Exploratory Study Comparing Workens' and Clients' Views," Family Service Association of America, New York, 1970.

Shyme, Ann W., "What Research Tella Us About Short Term Cases in Family Agencies," Social Cesework, Vol. XXXVIII, No. 5, May, 1957.

Siegal, Natalie, "A Follow-up Study of Former Clients: An Example of Praotioner-Directed Research," Social Casework, Vol. XIVI, No. 6, June, 1965.

Stark, Frances B., "Barriers to Client-Worker Communication at Intake," Social Casework, Vol. XL, April, 1959.

Thomas, Edwin, Polansky, Norman and Kounin, Jacob, "The Bxpected Behavior of a Potentially Helpful Person," Euman Belations, Vol. VIII, May, 1955. 


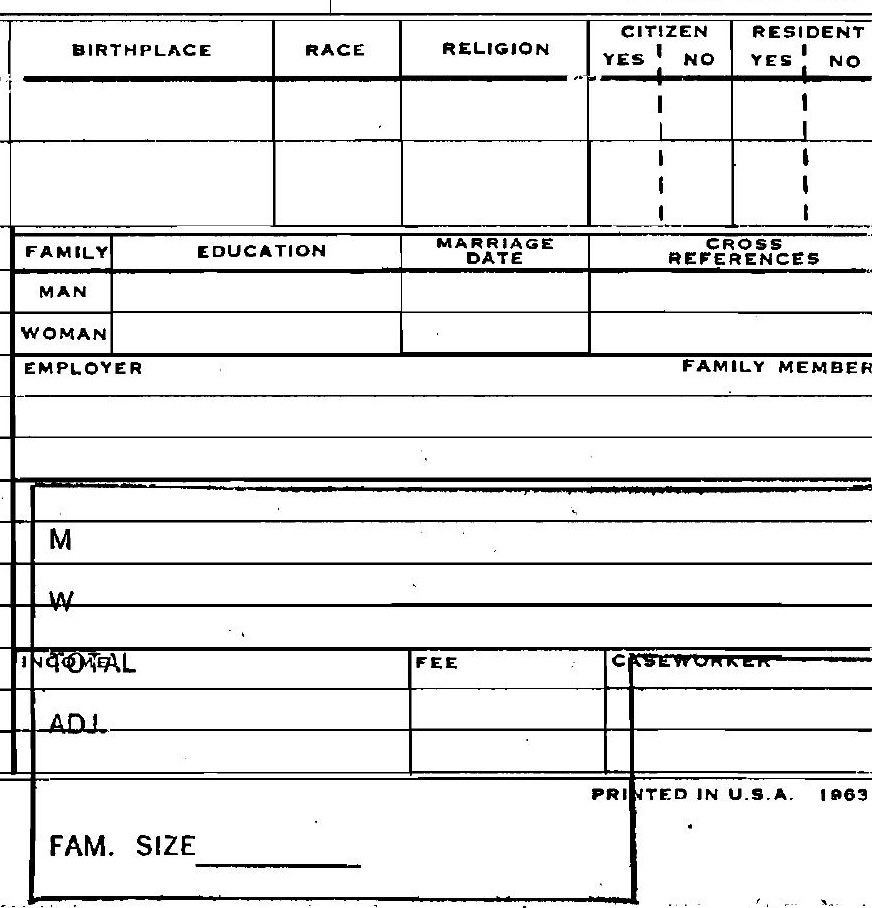

\section{PRIMARY FOCUS OF SERVICE}

I FaMILY and INDIVIDUAL RELATIONSHIPS

\section{1. - MARITAL RELATIONSHIPS}

2. - PARENT-CHILD RELATIONSHIP OR RELATIONSHIP

- OF INDividual CHILD UNDER is

3. - OTHER FAMILY RELATIONSHIPS OR RELATIONSHIPS

OF INDIVIDUAL ADULTS

If Environmental or situational conortions

5. -_ financial difficulty.

6. - physical illesess or hamdicap

7. — MEMTAL ILLMESS

- _. intellectual retardation

- - arramgements for physical care 10. _OTHER ENVIRONMENTAL OR SITUATIONAL
CONDITION

III OTHER

11. — Report given on terminated service

12. — INQUiRY MADE FOR OUT-OF-TOWM AGENCY

\section{REASON FOR TERMINATION}

I TEL. OR CORR. ONLY WITH FAMILY OR CONTACT ON BEHALF OF FAMILY

1. _._ FAMILY DID NOT FOLLOW THRU

2. _ REFERRED ELSEWHERE

3. - presenting request or neEd

3. - PRESET MY AGENCY

4. LEPORT GIVEN ON TERMINATED

5. Timbice

3. — ImQuiRY MADE For OUT-OF-town

6. SEGEICE not aVALLAGLE

II IN-PERSON INTERVIEW(S) WITH FAMILY

$$
\begin{aligned}
& \text { 7. DEFERRED ELSEWHERE } \\
& \text { 9. SERVICE IERMINATED BY } \\
& \text { 9. CASEWORK PLAN } \\
& \text { 10. FAMILY WITHDREW OR } \\
& \text { TERMINATED SERVICE } \\
& \text { FURTHER SERVICE NOT POSSIBLE }
\end{aligned}
$$

\section{FINANCIAL ASSISTANCE GIVEN}

\section{DATE TERMINATED}

CATEGORY OF SERVICE AT TERMINATION

- TEL, OR CORR. ONLY WITH FAM.

_ ONE IN-PERS. INTERVIEW WITH FAM.

2-S IN-PERS. 1NT. WITH FAM.

- OR more in.pens. int. with fam. THRU CONTACT WITH FAMILY - THRU CONTACT ON BEHALF OF FAMILY

Number of Gropn Sessions

IN-PERSON INTERVIEWS WITH CLIENTS (CHECK ONE OR MORE)

A. Ctfice interviews

B. Honie visits physical incapacity other reasons

C. Family Group Interviews

\begin{tabular}{l} 
EVALUATION \\
OF SERVICE \\
\hline SUBSTANTIAL GAIN \\
MODERAIE GAIN \\
SLIGHT GAIN \\
NO CIIANGE \\
UNABLE TO DETERMINE
\end{tabular}

FAMILY AND INDIVID. UAL RELATIONSHIPS SIT:ATICAAL COWI. 


\title{
FAMILY COUNSELING SERVICE
}

2281 N. W. EVERETT ST. PORTLAND. OREGON $97210 \cdot 228.7238$

ACCREDITED AGENCY

FAMILY SERVICE ASSOCIATION

OF AMERICA

\author{
February 5, 1971
}

\section{Dear}

In 1969 you came to Family Counseling Service for help with a problem. We are eager to know whether or not you recelved the help you needed. Your opinion really counts to us so that we can help serve others in the future in a better way.

Wi1l you help us? Please answer these few questions now, and put them in the mail right away.

This questionnalre is strictly confidentlal and for agency use only. This material will not be made public.

Thank you very much for your help.

$$
\text { Sincerely, }
$$

(Miss) Katherine Clark Executive Director

sp

encl: questionnalre

\section{OFFICERS}

R. 3. NOVOTNY

President

PAUL G. COOK

Vice-Presidon!

BARNES H. ELLIS

Vice-President

MRS. DONALD J. STERLING. JR.

Socretory

WILLIAM G CONUEY
BOARD OF DIRECTORS

LOWELL C. ASHEAUGH

MRS. JOHN P. BLEDSOE

MRS. JAMES E. BRYSON

CLIFFORD 1. CAMPBELL

ROBERT P. DEKONING

STUART KERR

PETER H. KOEHLER

MRS. DAVID J. LEWIS JOE T. LIENERT
IRVIN H. LUITEN

ROSCOE C. NELSON DENNIS J. O'TOOLE MRS. HAROLD M. PHILLIPS MRS. FORREST E. RIEKE BEATRICE K. ROSE, M.D. MRS. VERNA SHEPHERD MRS. HUGH STITES FREDERIC G. WESSINGER 
In order to be of maximum help to us, please complete all questions.

1. Describe briefly the problem that brought you to us for help.

2. Would you say the problem was mostly: a personal problem a husband-wife problem a parent-child problem other

3. Can you tell us in a sentence or two to what extent you were helped?

4. Would you say that you were helped: (Please check only one)

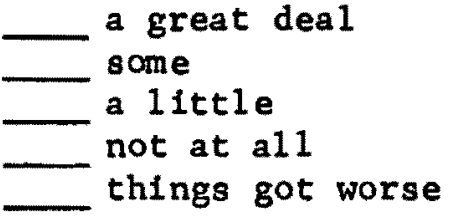

5. What were the reasons you stopped coming to the agency?

6. Was it you decision alone to stop coming?

Was it the worker's decision?

Was it a joint decision between you and your worker?

7. Were there other important reasons than the above that made you decide to stop coming, such as: Transportation, distance from the agency

Babysitting problems

- Agency hours not convenlent Fee Moved away Spouse unable to participte Other (describe)

Found help elsewhere (describe)

Please return the completed questionnalre to Family Counseling Service, 2281 N.W. Everett Street, Portland, Oregon 97210, by February 12, 1971. Thank you for your help. 